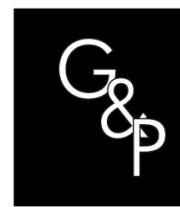

Thematic

Section

Digital

Transformation,

Intelligent

Manufacturing

and Supply

Chain

Management 4.0

\title{
An exploratory study on emerging technologies applied to logistics 4.0
}

\author{
Um estudo exploratório sobre tecnologias emergentes aplicadas à \\ logística 4.0
}

\author{
Jobel Santos Corrêa ${ }^{1}$ (D), Mauro Sampaio² (D), Rodrigo de Castro Barros ${ }^{2}$ (D) \\ ${ }^{1}$ Faculdade Estácio de Santo André, Faculdade de Engenharia de Produção, Santo André, SP, Brasil. \\ E-mail: jobel.correa@gmail.com \\ ${ }^{2}$ Centro Universitário da FEl, Departamento de Engenharia de Produção, São Bernardo do Campo, SP, Brasil. \\ E-mail: msampaio@fei.edu.br; 84.rbarros@gmail.com
}

\begin{abstract}
How to cite: Corrêa, J. S., Sampaio, M., \& Barros, R. C. (2020). An exploratory study on emerging technologies applied to logistics 4.0. Gestão \& Produção, 27(3), e5468. https://doi.org/10.1590/0104$530 \times 5468-20$
\end{abstract}

\begin{abstract}
The concept of Logistics 4.0 works closely to that of Industry 4.0. While Industry 4.0 proposes a disruptive change in manufacturing, Logistics 4.0 advocates a transformation in the way organizations buy, manufacture, sell, and deliver products. The objective of this paper is to identify, in Brazilian companies, the degree of interest in the investment in six emerging technologies applicable to logistics, according to scientific literature, as well as to identify the current perception of data quality of these companies. To achieve these objectives, an online survey was conducted. The research showed that the technologies that most interest Brazilian companies are Internet of Things (IoT) and cloud computing, both with $82 \%$ of investment intention. The two technologies that least interested companies are crowdsourcing and 3D printing, both with $68 \%$ investment disinterest among respondents.
\end{abstract}

Keywords: Logistics 4.0; Industry 4.0; Investment; Emerging technologies.

Resumo: O conceito de Logística 4.0 é análogo ao da Indústria 4.0. Enquanto a Indústria 4.0 propõe uma mudança disruptiva na manufatura, a Logística 4.0 defende uma transformação na forma como as organizações compram, fabricam, vendem e entregam produtos. O objetivo deste artigo é identificar, nas empresas brasileiras, o grau de interesse no investimento em seis tecnologias emergentes aplicáveis à logística, de acordo com a literatura científica, bem como identificar a percepção atual da qualidade dos dados dessas empresas. Para atingir esses objetivos, foi realizada uma pesquisa online. A pesquisa mostrou que as tecnologias que mais interessam às empresas brasileiras são Internet das Coisas (loT) e computação em nuvem, ambas com $82 \%$ de intenção de investimento. As duas tecnologias que menos interessam às empresas são crowdsourcing e impressão 3D, ambas com desinteresse de $68 \%$ pelos investimentos dos entrevistados.

Palavras-chave: Logística 4.0; Indústria 4.0; Investimento; Tecnologias emergentes.

Received Apr. 23, 2019 - Accepted May 30, 2020

Financial support: This paper was possible with the support of the Coordenação de Aperfeiçoamento de Pessoal de Nível Superior Brasil (CAPES) - Financing Code 001.

This is an Open Access article distributed under the terms of the Creative Commons Attribution License, which permits unrestricted use, distribution, and reproduction in any medium, provided the original work is properly cited. 


\section{Introduction}

The study of logistics 4.0 is one of the most discussed subjects in the area of logistics and supply chain management (Wang, 2016; Strandhagen et al., 2017). There are several well-known enabling technologies for Logistics 4.0, such as Internet of Things (loT), Big Data Analytics (BDA), Cloud, Blockchain, 3D Printing, Crowdsourcing, among others. The term Logistics 4.0 includes the application of emerging technologies, seeking efficiency improvements in logistics processes (Pfohl et al., 2015). However, little is known about the level of adoption and/or interest of these technologies in the market, mainly among logistics and supply chain management professionals in a developing country like Brazil. There are other enabling technologies for Industry 4.0, but this work will focus exclusively on technologies mentioned above.

There are studies in literature on applications and impacts of the Industry 4.0 concept, mainly in areas of manufacturing, design and collaborative robotics, but there are few studies on Logistics 4.0 in organizations. For Drees $(2016$, p. 1) "[...] the prerequisite for Industry 4.0 is Logistics 4.0 ". However, there are few studies on emerging technologies applied to logistics, as reported by Pfohl et al. (2015, p. 35), "[...] organizations need to understand how logistics and the supply chain will be impacted by emerging technologies". In addition, Strandhagen et al. (2017, p. 241) argued "[...] what are the key elements and emerging technologies of Industry 4.0 related to logistics?"

The theme Logistics 4.0 is relevant to the academic environment due to its contemporaneity and its intrinsic connection with the Industry 4.0 concept. The topic is also of interest to logistics companies and professionals working in this area. According to IBGE (2018), logistics operators (transport, inventory, storage and administrative services companies) account for $4.5 \%$ of the national GDP, which is equivalent to $\mathrm{R} \$ 297$ billion in 2017. It is important to understand the impacts of emerging technologies linked to the concept of Logistics 4.0 and its potential benefits for companies and society, for example, reducing road traffic by the use of shared freight, optimizing delivery routes to decrease the number of vehicles used in the last mile and decreasing the time of business transactions.

The aim of this work was to understand, describe and investigate the level of adoption and interest in new enabling technologies of Logistics 4.0 in order to identify the main factors that affect implementation, mainly the expected or already obtained gain. All concepts related to Logistics 4.0 were developed in order to explore these emerging technologies and find out which ones best suit the reality of the logistics of Brazilian companies.

To achieve the objectives proposed in this work, a survey was carried out using the online survey method to collect and compile data to evaluate the perception of executives from Brazilian companies regarding investment in emerging technologies.

Rogers et al. (2017) carried out a study on this theme, but focused on investigating only the adoption of Big Data Analytics technology, but this study is broader and investigates the adoption of six types of technologies associated with logistics 4.0.

This study is divided into four sections, in addition to the introduction. The second section shows the historical evolution of the Logistics 4.0 concept. The next section discusses the methodology used in the study. The search results are then presented. Conclusion is in the fifth and last section. 


\section{Literature review}

This literature review shows the state of the art on Logistics 4.0 and the emerging technologies linked to this concept.

\subsection{Evolution of logistics processes}

Logistics has undergone three changes in the past: the first (logistics 1.0) occurred at the end of the Nineteenth century and beginning of the Twentieth century with the introduction of steam mechanization, replacing men and animal traction as means of transport. The second (logistics 2.0) occurred with the discovery of electric energy and the introduction of mass production. The third (logistics 3.0) occurred with the systematization of logistics management and the introduction of microcomputers and communication technologies in the 1980s (Wang, 2016).

\subsection{Industry 4.0 and Logistics 4.0}

For Hofmann \& Rüsch (2017), Industry 4.0 is a concept conceived in Germany in 2011 related to intelligent factories with vertically and horizontally integrated production systems and individualized mass production made possible by highly flexible industrial processes. For the full potential promised by Industry 4.0 to be achieved, a logistics system consistent with its concepts is required. A logistics system that meets the requirements imposed by Industry 4.0 is known as logistics 4.0 (Wang, 2016). For Drees (2016, p. 1) "[...] the prerequisite for Industry 4.0 is Logistics 4.0" For Strandhagen et al. (2017), Logistics 4.0 appears as a result of recent advances in the IT and communications area combined with the need for greater automation and digitalization of operations and processes in the manufacturing segment.

\subsection{Emerging technologies linked to Logistics 4.0}

In order to identify, in recent literature, which emerging technologies are considered most promising for practical applications in the field of logistics, a literature review was carried out using the ProKnow-C method (Knowledge Development Process Constructivist). This method allows to quantitatively analyzing articles relevant to the research topic, systematizing the process of searching and selecting articles (Vilela, 2012). The following keywords were selected (in Portuguese and English): a) logistics; b) logistics 4.0; c) emerging technologies; d) applications in logistics; e) electronics; f) computing; g) telecommunications; h) databases; i) autonomous devices; j) distributed processing; k) internet; I) digital supply chains; $m$ ) transaction records; $n$ ) information security; o) data storage and p) shared data access. After selecting keywords, they were searched in the following databases: SciELO (Scientific Electronic Library Online), Scopus, Web of Science, IEEE Xplore, Elsevier Directory of Open Access Journals (DOAJ), ScienceDirect, ArXiv, ScienceResearch.com, CAPES Portal, Brazilian Digital Library of Theses and Dissertations (BDTD) and Google Scholar. After applying the ProKnow-C method, a main portfolio of 20 articles emerged, detailed in Chart 1 , showing the following emerging technologies as being the most promising for practical applications in the area of logistics: a) internet of things (loT); b) big data analytics (BDA); c) cloud; d) blockchain; e) 3D printing and d) crowdsourcing. Chart 1 
summarizes the literature review of emerging technologies linked to the Logistics 4.0 concept.

Chart 1. Emerging technologies with potential for use in Logistics 4.0.

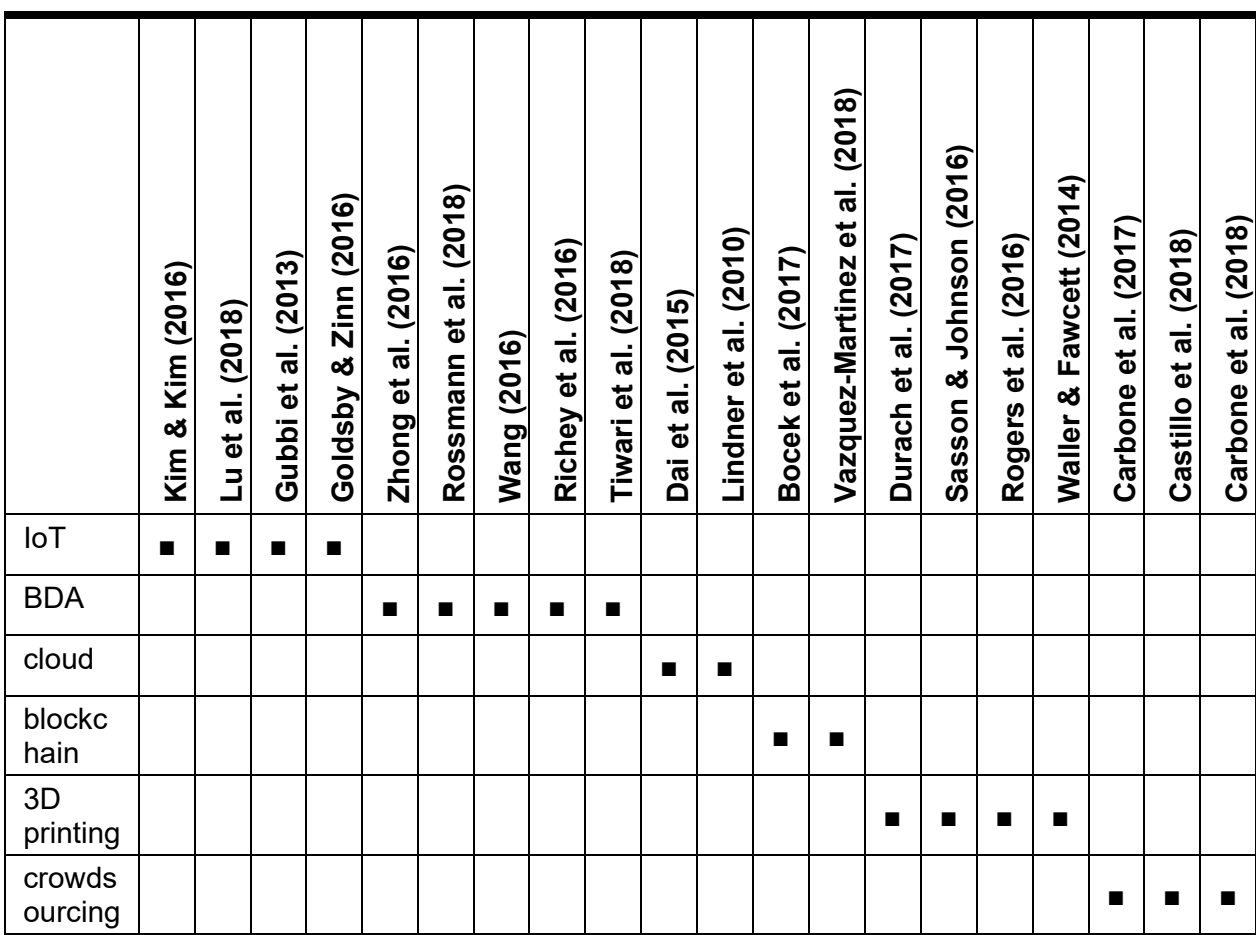

Source: Authors.

\subsection{Internet of Things (loT)}

The internet of things is a technological paradigm that aims to connect anything and anyone, anytime and anywhere (Lu et al. (2018, p. 1). For Goldsby \& Zinn (2016), loT will give rise to new and innovative services and applications Gubbi et al. (2013) explain that this connection occurs through the use of a worldwide network of interconnected objects exclusively addressed based on standard communication protocols. Kim \& Kim (2016) report that one of the areas benefited with the adoption of loT is logistics. Figure 1 shows an example of visibility in the supply chain using the loT technology.

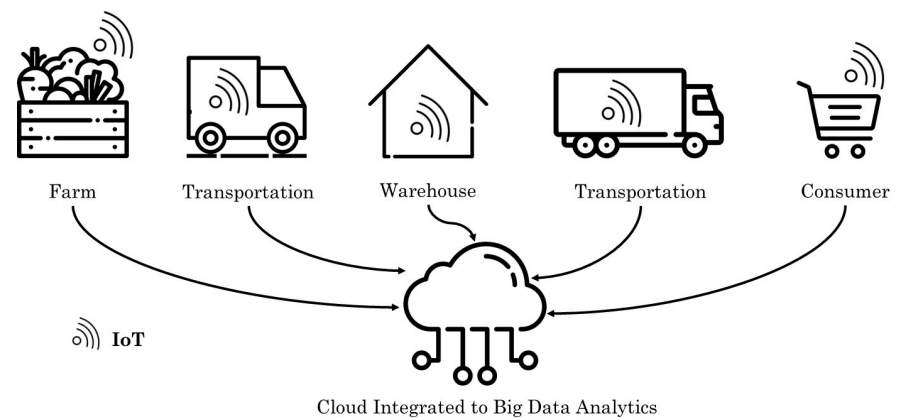

Figure 1. Supply chain visibility using loT devices. Source: Authors. 


\subsection{Big Data Analytics (BDA)}

The growing amount of data created the need for the development of business intelligence technologies that are summarized under the term Big Data Analytics (BDA) (Rossmann et al., 2018). According to Tiwari et al. (2018), big data can be defined as large and complex data sets with current size of one exabyte ( $10^{18}$ bytes), reaching one zettabyte ( $10^{21}$ bytes) per year. According to Zhong et al. (2016), BDA deals with the " $5 \mathrm{~V}$ " concept: the volume dimension deals with the amount of data, the velocity dimension is important for decision making, the variety dimension deals with the heterogeneity of data sources, the veracity dimension eliminates invalid data, finally, the value dimension transforms big data into added value for organizations (Richey et al., 2016). Figure 2 shows the variation in volume and velocity of data used in supply chain management according to their variety (or structure).

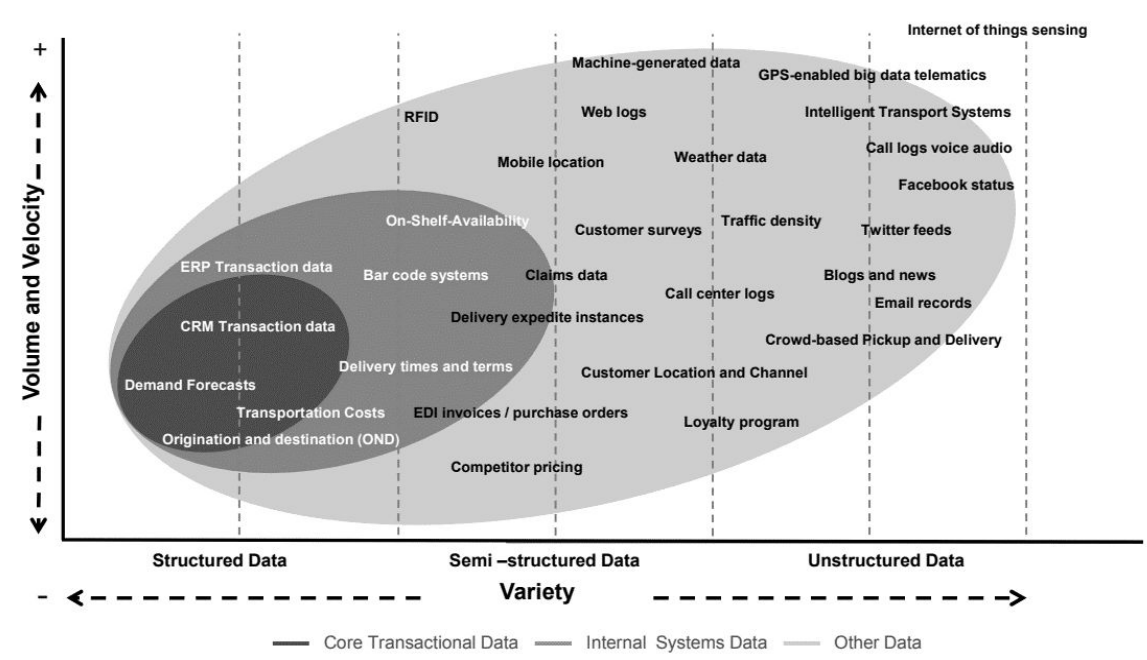

Figure 2. Volume and velocity of SCM data vs. data variety in SCM. Source: Authors, adapted from Varela Rozados \& Tjahjono (2014, p. 8).

\subsection{Cloud}

Cloud is a computing paradigm in which tasks are assigned to a combination of connections, software and services accessed on a network (Dai et al., 2015). This network of servers and connections is collectively known as "the cloud". Bhoir \& Principal (2014) report that users can access resources as needed and the cloud architecture can manage a variety of different workloads and that clouds dedicated to supply chain management are known as cloud supply chain (CSC). For Lindner et al. (2010) the cloud supply chain represents a network of businesses interconnected by technology, involved in the supply of end-to-end products and service packages required by customers. Chart 2 shows the differences between a traditional supply chain and cloud-based supply chains. 
Chart 2. Traditional supply chain vs. cloud supply chain.

\begin{tabular}{|l|l|l|}
\hline Main objective & \multicolumn{1}{|c|}{ Traditional Supply Chain } & \multicolumn{1}{c|}{ Cloud Supply Chain } \\
\hline $\begin{array}{l}\text { To meet the demand for the } \\
\text { lowest cost level }\end{array}$ & $\begin{array}{l}\text { Meet demand at the lowest cost } \\
\text { level and respond quickly to } \\
\text { demand. }\end{array}$ \\
\hline strategy design & $\begin{array}{l}\text { Maximize performance at } \\
\text { minimum product cost }\end{array}$ & $\begin{array}{l}\text { Create modularity to allow } \\
\text { individual configuration while } \\
\text { maximizing service performance. }\end{array}$ \\
\hline Price strategy & $\begin{array}{l}\text { Lower margins because price is } \\
\text { the main factor for the customer. }\end{array}$ & $\begin{array}{l}\text { Lower margins, offering high } \\
\text { competition to comparable } \\
\text { products. }\end{array}$ \\
\hline strategy & Lower costs with high utilization. & $\begin{array}{l}\text { High utilization while flexibly } \\
\text { reacting to demand. }\end{array}$ \\
\hline $\begin{array}{l}\text { Lead-time } \\
\text { strategy }\end{array}$ & $\begin{array}{l}\text { Minimize inventory to reduce } \\
\text { costs }\end{array}$ & $\begin{array}{l}\text { Optimize buffer to meet } \\
\text { unpredictable demand. }\end{array}$ \\
\hline Seduce, but not at the expense & $\begin{array}{l}\text { Strong service level agreement } \\
\text { (SLA) }\end{array}$ \\
\hline Supplier strategy & $\begin{array}{l}\text { Select suppliers based on cost } \\
\text { and quality. }\end{array}$ & $\begin{array}{l}\text { Select suppliers based on the } \\
\text { optimal complex of velocity, cost } \\
\text { and flexibility. }\end{array}$ \\
\hline $\begin{array}{l}\text { Transport } \\
\text { strategy }\end{array}$ & $\begin{array}{l}\text { Greater reliability in low-cost } \\
\text { modes. }\end{array}$ & $\begin{array}{l}\text { Implement highly responsive and } \\
\text { low-cost modes. }\end{array}$ \\
\hline
\end{tabular}

Source: Author adapted from Lindner et al. (2010, p. 6).

\subsection{Blockchain}

Contracts and transaction records form the basis of our economic, legal and political system, protecting assets, establishing organizational boundaries and verifying transactional identities and events, governing interactions between nations, organizations, communities and individuals (Vazquez-Martinez et al., 2018). Blockchain technology is characterized as a distributed, decentralized and open-source database to store information about transactions. These transactions are executed without depending on a third party (such as a bank or registry, for example), but rather on distributed trust based on a blockchain network. Bocek et al. (2017) state that transactions can be stored in the form of smart contracts within a blockchain network. Smart contracts are data from a logistical transaction stored on a network with blockchain technology, with unique address, which can be accessed so that the transaction can be read, but not to change it after completed (Kshetri, 2018). Figure 3 shows an example of asset tracking using smart contracts, blockchain and loT. In Figure $3 a$ (left), a container leaves factory $(A)$, arrives at the neighboring port $(B)$ via rail, is transported to the destination port (C) and then to the distributor's facilities (D) until reaching the retailer $(E)$. Figure $3 b$ (right) is focuses on stage $B-C$. The container transporting ship performs a handshake (digital confirmation) with the destination port (C) confirming that the container is delivered to the expected location. When this handshake is completed, the delivery data must be sent to a smart contract, completing the delivery. The smart contract is stored on a blockchain network and its data are transmitted via loT technology. The destination port will also confirm receipt of the container within an estimated deadline. If the destination port (C) does not publish in the contract within this period, the company will know and be able to take appropriate measures. 


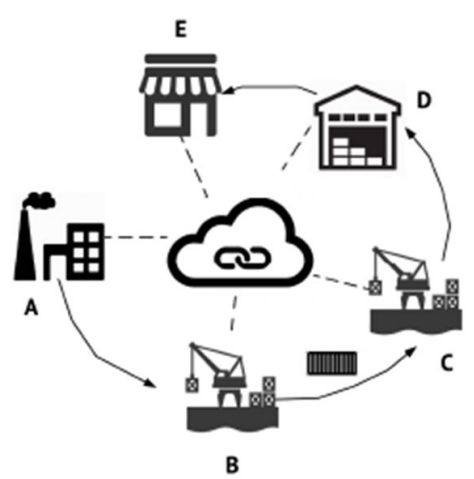

(a)

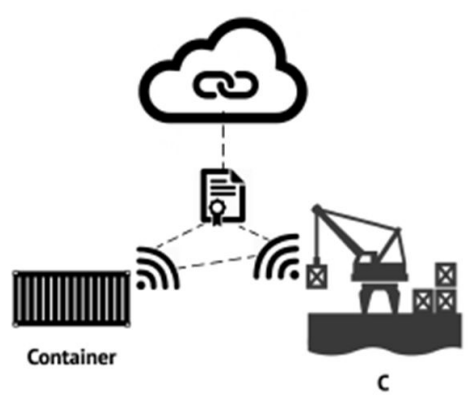

(b)

Figure 3. Example of tracking using smart contracts, blockchain and loT. Source: Authors adapted from Christidis \& Devetsikiotis (2016, p. 2299).

\subsection{D printing}

According to Waller \& Fawcett (2014), additive manufacturing, also known as 3D printing, is an emerging technology that can transform the supply chain. Rogers et al. (2016) cite that 3D printing was originally used for rapid prototyping. Currently, 3D printing technologies have assumed an important part of manufacturing processes (Sasson \& Johnson, 2016), printing locally end products economically viable, avoiding the physical distribution stage of some products (Durach et al., 2017). Figure 4 shows the impact of 3D printing on supply chains.

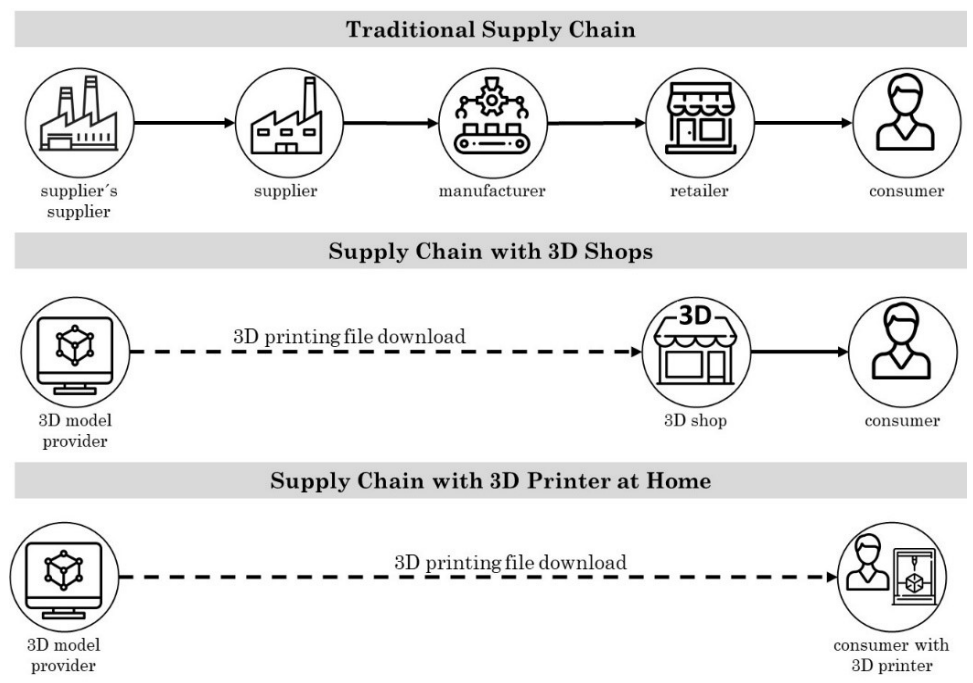

Figure 4. Impact of 3D printing on supply chains. Source: Authors, adapted from Kubáč \& Kodym (2017, p. 4).

Using supply chains supported by 3D printer, end customers can obtain a file with the description of the physical product they want to purchase. The file is then taken to a 3D printer to print the final product or the file is uploaded online. The final product does not need to move among the various actors in the supply chain, but rather be sent from the supplier to the end customer and printed in a 3D printer. When inexpensive 
and easy-to-configure 3D printers are available, products can be printed by end consumers (Waller \& Fawcett, 2014).

\subsection{Crowdsourcing}

Collaborative forms of consumption where one or more people consume economic goods or services in the process of engaging in joint activities with others is known as collaborative consumption, Carbone et al. (2018). In this collaboration scenario, practices known as crowdsourcing and crowdfunding emerge. Howe (2006) reports that the term crowdsourcing was conceived to represent the outsourcing of works from companies to a large group of individuals or crowd using electronic means of communication. Carbone et al. (2017) report that crowdsourcing is a new way to provide logistics services that take advantage of individuals' inactive resources and logistics potential using mobile applications and web-based platforms. Castillo et al. (2018) report that one of the areas benefited by the concept of crowdsourcing is logistics.

\subsection{Conceptual model for Logistics 4.0}

The model for Logistics 4.0 shown in Figure 5 is then proposed. Lambert (1975) designed a model of a logistics system based on five points: a) service level, b) transport, c) storage, d) inventories and e) purchases and sales. We then propose an improvement in the model designed by Lambert (1975), used until today, with the inclusion of a new external layer, where emerging technologies mentioned in the literature review are incorporated into the traditional model. This layer is responsible for coordinating all the complexity of data and their transformation into managerial information, thus collaborating with literature in the area of logistics.

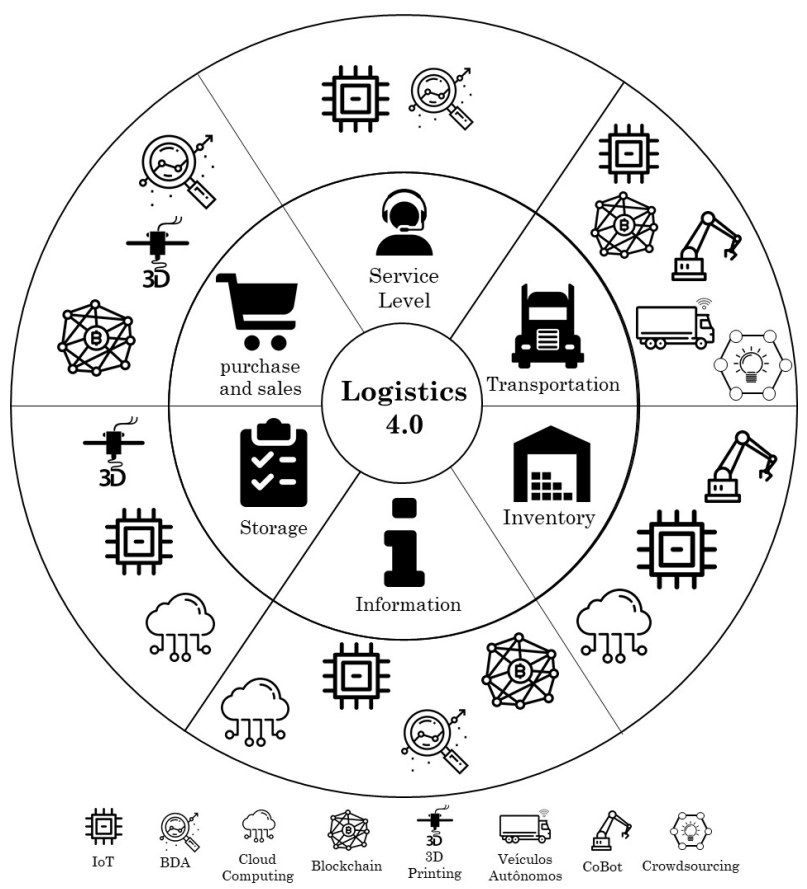

Figure 5. Conceptual model for Logistics 4.0. Source: Authors. 
The model proposed for Logistics 4.0 takes into account the following applications of emerging technologies:

a) Service level: the six emerging technologies cited in literature can be used to improve the company's service level, helping to ensure that the demand is met.

IoT identifies inputs and goods (Kim \& Kim, 2016), BDA identifies consumption patterns (Waller \& Fawcett, 2013), cloud stores data related to operations (Dai et al., 2015), blockchain guarantees validity of commercial transactions (Bocek et al., 2017), 3D printing allows local printing of components, avoiding logistical traffic (Waller \& Fawcett, 2014) and, finally, crowdsourcing improves lead-time (delivery time) through the sharing of road assets (Castillo et al., 2018).

b) Transport: IoT (Lu et al., 2018), blockchain (Kshetri, 2018) and crowdsourcing (Carbone et al., 2018) deal with the tracking, inviolability and agility of transport, streamlining the entry and exit logistics;

c) Storage: IoT (Lu et al., 2018), blockchain (Bocek et al., 2017) and BDA (Wang, 2016) can ensure that inputs and goods are being stored in locations the closest to points of consumption as possible, improving lead-time;

d) Information: this new activity incorporated into the model proposed by Lambert (1975) has the function of managing all the complexity of data and operational, managerial and strategic information generated by these data. loT technology provides data on the movement of goods and inputs. Transactions are validated by blockchain technology and stored in CSC (Lindner et al., 2010). Intelligent systems streamline the delivery of inputs and goods and all this technological apparatus is coordinated by one or more BDA systems (Richey et al., 2016);

e) Inventories: maintaining correct inventory levels is a vital operation for the company's financial health. According to Hofmann (2017), aided by other technologies (such as loT, cloud, 3D printing and blockchain), BDA allows to improve demand forecasting and to identify consumption patterns, sending inventory disruption and mitigating the "bullwhip effect", a well-known phenomenon that generates inefficiencies in the supply chain by responding, with large fluctuation in inventories, to a small variation in the number of consumer orders;

f) Purchase and sale: according to Bocek et al. (2017), the blockchain technology allows the verification and digital authentication of all transactions carried out by the company, either the purchase of inputs from suppliers or the sale of finished products. The loT technology allows the tracking of deliveries via internet of all operations associated with delivery, and the BDA technology generates data and information linked to this logistics operation (Wang, 2016).

\section{Methodology}

This section presents the research method used, the operationalization of variables, pre-test of the research instrument, population and sample, data collection and procedures for data analysis. 


\subsection{Research type}

This study uses a quantitative, cross-sectional online survey research method, with non-probabilistic sample of the population of interest to collect data, compile data and perform hypothesis tests (Parasuranan et al., 2006).

\subsection{Population and sample}

The study population was composed of national and multinational companies operating in Brazil. A non-probabilistic convenience sampling of companies that are part of the "Tecnologística" portal database was carried out. This magazine has 26,000 subscribers mainly composed of logistics and supply chain management professionals mainly working in Brazilian companies. The questionnaire was sent to all subscribers to this magazine, which is similar to work carried out by Rogers et al. (2017), which used the database of professionals linked to the Council Supply Chain Management Professional (CSCMP, 2017).

\subsection{Data collection}

The survey was conducted between August and November 2018. At the beginning of August 2018, the electronic address (link) for completing the survey was sent to the representative of all Brazilian companies registered in the "Tecnologística" portal database. The portal's subscriber database has about 26,000 companies. Overall, 116 questionnaires were obtained between August and November 2018, of which 8 (6.9\%) were discarded. Of these, two questionnaires were incomplete. Respondents were asked to evaluate the missing questions and resubmit the questionnaire. Respondents did not do so. Four questionnaires had filling inconsistencies and were discarded for this reason. Thus, 108 valid responses were analyzed in this study. The raw data used in this article are available for download, see the supplementary material section for futher information.

Although the sample is non-probabilistic and the number of respondents was low $(0.42 \%)$, its participants are legitimate representatives of Brazilian companies and capable of providing reliable data for the survey, as shown in Table 1.

\subsection{Operationalization of variables}

The research form adopted in this work was based on the model used in the Big Data Analytics in Supply Chain research (Rogers et al., 2017). The scales for measuring variables gain in financial investment and time for gain realization regarding the financial investment in the six emerging technologies mentioned here were obtained from this work.

The scales for measuring the degree of data quality are based on scales developed by Dong et al. (2001).

The present study uses some variables similar to those used in the works of Rogers et al. (2017) and Dong et al. (2001), but the objective and context differ from those of these studies. Rogers et al. (2017) analyzed only the big data adoption process in American companies and Dong et al. (2001) analyzed the relationship between customer and supplier among American companies. 


\subsection{Operational definition of variables}

Chart 3 presents the operational definition of variables and their respective metric scales.

Chart 3. Operational definition of variables.

\begin{tabular}{|c|c|c|c|}
\hline Variable & Measure & Scale & Source \\
\hline \multirow{6}{*}{ Gain } & Expected gain for investing in loT & \multirow{6}{*}{$\begin{array}{l}\text { 5-point } \\
\text { Likert: } \\
\text { [1] No gain } \\
\text { up to } \\
\text { [5] High } \\
\text { gain. }\end{array}$} & \multirow{6}{*}{$\begin{array}{l}\text { Rogers et al } \\
\qquad(2017)\end{array}$} \\
\hline & Expected gain for investing in BDA & & \\
\hline & Expected gain for investing in cloud & & \\
\hline & Expected gain for investing in blockchain & & \\
\hline & Expected gain for investing in 3D printing & & \\
\hline & Expected gain for investing in crowdsourcing & & \\
\hline \multirow{6}{*}{ Time } & Expected time to realize gains with loT & \multirow{6}{*}{$\begin{array}{l}\text { 5-point } \\
\text { Likert: } \\
\text { [1] No gain } \\
\text { up to } \\
\text { [5] High } \\
\text { gain }\end{array}$} & \multirow{6}{*}{$\begin{array}{l}\text { Rogers et al } \\
\qquad(2017)\end{array}$} \\
\hline & Expected time to realize gains with $\mathrm{BDA}$ & & \\
\hline & Expected time to realize gains with cloud & & \\
\hline & Expected time to realize gains with blockchain & & \\
\hline & Expected time to realize gains with $3 \mathrm{D}$ printing & & \\
\hline & Expected time to realize gains with crowdsourcing & & \\
\hline \multirow{5}{*}{$\begin{array}{l}\text { Data } \\
\text { quality }\end{array}$} & $\begin{array}{l}\text { company's data is stored in appropriate (reliable) } \\
\text { formats }\end{array}$ & \multirow{5}{*}{$\begin{array}{l}\text { 5-point } \\
\text { Likert: } \\
\text { [1] I totally } \\
\text { disagree } \\
\text { Up to } \\
\text { [5] I fully } \\
\text { agree }\end{array}$} & \multirow{5}{*}{$\begin{array}{l}\text { Dong et al. } \\
(2001)\end{array}$} \\
\hline & $\begin{array}{l}\text { I can easily access my company's data } \\
\text { (accessible) }\end{array}$ & & \\
\hline & $\begin{array}{l}\text { All organizational functions have the same data } \\
\text { (unique) }\end{array}$ & & \\
\hline & $\begin{array}{l}\text { My company data can be exchanged with my } \\
\text { supply chain (available) }\end{array}$ & & \\
\hline & $\begin{array}{l}\text { My company already exchanges data and } \\
\text { information with suppliers and / or customers } \\
\text { (collaborative) }\end{array}$ & & \\
\hline
\end{tabular}

Source: Authors.

\subsection{Statistical methods of analysis}

To perform the statistical analysis of data, the IBM SPSS Statistics software was used. a) For multiple-choice variables, the following statistical analysis methods were used: a) descriptive statistics (mean and standard deviation); b) frequency tables; c) X2 test (Pearson's chi-square); d) For variables measured by the Likert scale, ANOVA follow-up test (using the Scheffe's procedure) was used.

\section{Results}

Table 1 shows the profile of companies that responded to the survey. The company size categorization follows the IBGE classification. 
Table 1. Profile of the responding companies.

\begin{tabular}{|c|c|c|}
\hline & $\begin{array}{l}\text { Frequency } \\
\text { (total 108) }\end{array}$ & $\%$ \\
\hline \multicolumn{3}{|l|}{ Company size } \\
\hline Large size $^{1}$ & 37 & 34.3 \\
\hline Medium size ${ }^{2}$ & 21 & 19.4 \\
\hline Small size ${ }^{3}$ & 27 & 25.0 \\
\hline Micro-enterprise ${ }^{4}$ & 23 & 21.3 \\
\hline \multicolumn{3}{|c|}{ Sector in which the company operates } \\
\hline e-Commerce & 8 & 7.4 \\
\hline Industry & 25 & 23.1 \\
\hline Retail & 7 & 6.5 \\
\hline Logistics Services ${ }^{5}$ & 35 & 32.4 \\
\hline Other Services ${ }^{6}$ & 27 & 25.0 \\
\hline Others & 6 & 5.6 \\
\hline \multicolumn{3}{|c|}{ Region of Brazil where company's headquarters are located } \\
\hline Northern & 0 & 0.0 \\
\hline Northeastern & 6 & 5.6 \\
\hline Midwestern & 3 & 2.8 \\
\hline Southeastern & 72 & 66.7 \\
\hline Southern & 27 & 25.0 \\
\hline
\end{tabular}

${ }^{1}$ Over 100 employees for commerce and services and over 500 employees for Industry. ${ }^{2}$ From 50 to 99 employees for commerce and services and from 100 to 499 employees for industry. ${ }^{3} 10$ to 49 employees for commerce and services and 20 to 99 employees for industry. ${ }^{4} \mathrm{Up}$ to 9 employees for commerce and services and up to 19 employees for industry. ${ }^{5}$ Includes storage, transportation, fleet management, risk management, etc. ${ }^{6}$ Includes consulting, information technology (IT), software development, etc. Source: Authors.

Large companies composed the largest group of respondents, with $34 \%$ of responses. The number of medium- and small-size companies and micro-enterprises shows that emerging technologies are of interest to companies of all sizes. Most respondents operate in the field of logistical services (including storage, transportation, fleet management, risk management companies, etc.) with $32 \%$ of responses, followed by companies providing other services (consultancies, IT companies, software development, etc.), with $25 \%$ of responses, showing that the majority of responses came from large companies in the logistics sector. The head office or main office is located in the southeastern region of Brazil for $67 \%$ of responding companies. Table 2 summarizes the profile of survey respondents regarding position held and age group.

Table 2. Profile of respondents.

\begin{tabular}{lcc}
\hline & $\begin{array}{c}\text { Frequency } \\
\text { (total 108) }\end{array}$ & \% \\
\hline Respondent's position in the company & & 13.0 \\
\hline President & 14 & 21.3 \\
\hline Vice-President / Director & 23 & 25.9 \\
\hline Manager & 28 & 4.6 \\
\hline Engineer & 5 & 16.7 \\
\hline Analyst / Specialist & 18 & 12.0 \\
\hline Supervisor / Coordinator & 13 & 6.5 \\
\hline Other & 7 & \\
\hline
\end{tabular}


Table 2. Continued...

\begin{tabular}{lcc}
\hline & $\begin{array}{c}\text { Frequency } \\
\text { (total 108) }\end{array}$ & \% \\
\hline Respondent's age group & & 9.3 \\
\hline 21 to 30 years & 10 & 30.6 \\
\hline 31 to 40 years & 33 & 41.7 \\
\hline 41 to 50 years & 45 & 7.4 \\
\hline 51 to 60 years & 8 & 11.1 \\
\hline Over 60 years & 12 & \\
\hline
\end{tabular}

Source: Authors.

The survey showed that managers accounted for $26 \%$ of responses, followed by vice-presidents or directors, with $21 \%$ participation and by presidents, with $13 \%$ of responses, showing that more than $60 \%$ of respondents belong to the top leadership of companies. The largest age group is composed of people aged 41-50 years, with $42 \%$ of responses showing that most respondents are experienced professionals in the market.

Table 3 summarizes the interest of companies in investing in emerging technologies.

Table 3. Summary of companies' interest in investing in emerging technologies.

\begin{tabular}{|c|c|c|c|c|c|c|c|c|c|c|c|c|}
\hline & \multicolumn{2}{|c|}{ ІоT } & \multicolumn{2}{|c|}{ BDA } & \multicolumn{2}{|c|}{ Cloud } & \multicolumn{2}{|c|}{ Blockchain } & \multicolumn{2}{|c|}{$\begin{array}{c}\text { 3D } \\
\text { Printing }\end{array}$} & \multicolumn{2}{|c|}{$\begin{array}{c}\text { Crowdso } \\
\text { urcing }\end{array}$} \\
\hline & $f$ & $\%$ & $f$ & $\%$ & $f$ & $\%$ & $f$ & $\%$ & $f$ & $\%$ & $f$ & $\%$ \\
\hline \multicolumn{13}{|c|}{ Does your company intend to invest? } \\
\hline Yes & 89 & 82.4 & 60 & 55.6 & 89 & 82.4 & 57 & 52.8 & 35 & 32.4 & 34 & 31.5 \\
\hline No & 19 & 17.6 & 48 & 44.4 & 19 & 17.6 & 51 & 47.2 & 73 & 67.6 & 74 & 68.5 \\
\hline \multicolumn{13}{|c|}{ When does your company intend to invest? } \\
\hline We have already invested & 70 & 64.8 & 35 & 32.4 & 70 & 64.8 & 23 & 21.3 & 15 & 13.9 & 11 & 10.2 \\
\hline $\begin{array}{l}\text { We will invest in the short term } \\
\text { (up to } 1 \text { year) }\end{array}$ & 13 & 12.0 & 19 & 17.6 & 13 & 12.0 & 17 & 15.7 & 2 & 1.9 & 12 & 11.1 \\
\hline $\begin{array}{l}\text { We will invest in the medium } \\
\text { term(between } 2 \text { and } 5 \text { years) }\end{array}$ & 3 & 2.8 & 5 & 4.6 & 3 & 2.8 & 13 & 12.0 & 12 & 11.1 & 6 & 5.6 \\
\hline $\begin{array}{l}\text { We will invest in the long } \\
\text { term(over } 5 \text { years) }\end{array}$ & 3 & 2.8 & 1 & 0.9 & 3 & 2.8 & 4 & 3.7 & 6 & 5.6 & 5 & 4.6 \\
\hline There are no investment plans & 19 & 17.6 & 48 & 44.4 & 19 & 17.6 & 51 & 47.2 & 73 & 67.6 & 74 & 68.5 \\
\hline \multicolumn{13}{|c|}{ What is the main reason for the investment? } \\
\hline Remain competitive & 54 & 50.0 & 39 & 36.1 & 54 & 50.0 & 20 & 18.5 & 10 & 9.3 & 16 & 14.8 \\
\hline Anticipate competition & 22 & 20.4 & 19 & 17.6 & 22 & 20.4 & 27 & 25.0 & 18 & 16.7 & 11 & 10.2 \\
\hline Customers' requirements & 11 & 10.2 & 2 & 1.9 & 11 & 10.2 & 7 & 6.5 & 1 & 0.9 & 1 & 0.9 \\
\hline Suppliers' requirement & 2 & 1.9 & 0 & 0.0 & 2 & 1.9 & 3 & 2.8 & 6 & 5.6 & 6 & 5.6 \\
\hline There are no investment plans & 19 & 17.6 & 48 & 44.4 & 19 & 17.6 & 51 & 47.2 & 73 & 67.6 & 74 & 68.5 \\
\hline
\end{tabular}

Responding companies show more interest in investing in loT and cloud, both with $82 \%$ investment intention, followed by BDA with $56 \%$ interest. These technologies have already received investments today, $65 \%$ of companies already invest in loT and cloud and $32 \%$ of companies already invest in BDA. The main reason for investing in emerging technologies is to maintain competitiveness, with $30 \%$ of responses, followed 
by anticipating competition, with $18 \%$ of responses. Table 4 shows the applications of emerging technologies in logistics, presented in the research in an open question and grouped by similarity.

Table 4. Intended applications.

\begin{tabular}{lcc}
\hline & $\begin{array}{c}\text { Frequency } \\
\text { (total 108) }\end{array}$ & \% \\
\hline Did not respond & 68 & 63.0 \\
\hline Blockchain for tracking goods & 10 & 9.3 \\
\hline 3D printing for printing small components on site & 6 & 5.6 \\
\hline BDA to lower operating costs & 5 & 4.6 \\
\hline Blockchain for tracking goods and smart contracts & 4 & 3.7 \\
\hline Increase the security of IT infrastructure using cloud & 4 & 3.7 \\
\hline loT for cargo tracking & 3 & 2.8 \\
\hline BDA to analyze consumer behavior & 2 & 1.9 \\
\hline BDA for forecasting & 2 & 1.9 \\
\hline Using cloud computing for the storage of documents & 2 & 1.9 \\
\hline Cloud computing to reduce capex value & 1 & 0.9 \\
\hline Crowdsourcing to reduce idle space on trucks & 1 & 0.9 \\
\hline
\end{tabular}

Source: Authors.

The application most cited by respondents was the use of blockchain technology in tracking goods, with $9 \%$ of responses. The large number of respondents who left this question unanswered shows that the practical applications of emerging technologies are not defined for most companies. Table 5 shows the barriers for the adoption of emerging technologies cited by companies.

Table 5. Barriers for the adoption of emerging technologies.

\begin{tabular}{|c|c|c|c|c|c|c|c|c|c|c|c|c|c|c|}
\hline & \multicolumn{2}{|c|}{ loT } & \multicolumn{2}{|c|}{ BDA } & \multicolumn{2}{|c|}{ Cloud } & \multicolumn{2}{|c|}{ Blockchain } & \multicolumn{2}{|c|}{$\begin{array}{c}\text { 3D } \\
\text { Printing }\end{array}$} & \multicolumn{2}{|c|}{$\begin{array}{l}\text { Crowdsour } \\
\text { cing }\end{array}$} & \multicolumn{2}{|c|}{ Total } \\
\hline & f & $\%$ & $f$ & $\%$ & $f$ & $\%$ & $f$ & $\%$ & f & $\%$ & f & $\%$ & f & $\%$ \\
\hline $\begin{array}{l}\text { Lack of adoption } \\
\text { strategy }\end{array}$ & 15 & 11.2 & 17 & 14.0 & 12 & 15.0 & 17 & 12.0 & 15 & 11.3 & 16 & 13.9 & 92 & 29.5 \\
\hline $\begin{array}{l}\text { High investment in } \\
\text { software and } \\
\text { hardware }\end{array}$ & 33 & 24.6 & 23 & 19.0 & 20 & 25.0 & 24 & 16.9 & 22 & 16.5 & 9 & 7.8 & 131 & 42.0 \\
\hline $\begin{array}{l}\text { High investment in } \\
\text { human resources }\end{array}$ & 17 & 12.7 & 22 & 18.2 & 18 & 22.5 & 26 & 18.3 & 12 & 9.0 & 7 & 6.1 & 102 & 32.7 \\
\hline $\begin{array}{l}\text { Difficulty } \\
\text { understanding how } \\
\text { technology adds } \\
\text { value to the business }\end{array}$ & 16 & 11.9 & 9 & 7.4 & 7 & 8.8 & 20 & 14.1 & 7 & 5.3 & 6 & 5.2 & 65 & 20.8 \\
\hline $\begin{array}{l}\text { Difficulty obtaining } \\
\text { support or approval } \\
\text { from higher levels } \\
\text { management }\end{array}$ & 6 & 4.5 & 2 & 1.7 & 4 & 5.0 & 4 & 2.8 & 4 & 3.0 & 3 & 2.6 & 23 & 7.4 \\
\hline $\begin{array}{l}\text { There are no } \\
\text { investment plans }\end{array}$ & 47 & 35.1 & 48 & 39.7 & 19 & 23.8 & 51 & 35.9 & 73 & 54.9 & 74 & 64.3 & 312 & 100.0 \\
\hline
\end{tabular}

This is a multiple choice question, the respondent can check more than one barrier, thus, the sum of the frequencies is not equal to the total responses $(N=108)$. Source: Authors. 
High investments in software and hardware, followed by high investments in human resources, are the most cited restrictions when it comes to emerging technologies such as IoT, BDA, cloud and blockchain. For 3D printing and crowdsourcing technologies, the most reported barriers are the absence of strategy for adopting the technology and the high investments in software and hardware. Table 6 summarizes other barriers for the adoption of emerging technologies.

Table 6. Other barriers for the adoption of emerging technologies.

\begin{tabular}{lcc}
\multicolumn{1}{c}{$\begin{array}{c}\text { Are there any other barriers for the adoption of emerging } \\
\text { technologies? }\end{array}$} & $\begin{array}{c}\text { Frequency } \\
\text { (total 108) }\end{array}$ & \% \\
\hline There are no other barriers & 72 & 67.3 \\
\hline Lack of human resources & 11 & 10.3 \\
\hline Lack of financial resources & 7 & 6.5 \\
\hline Lack of specific training in blockchain & 4 & 3.7 \\
\hline Approval from company headquarters & 3 & 2.8 \\
\hline Lack of professionals qualified in emerging technologies & 3 & 2.8 \\
\hline Lack of ready BDA 3 packages in the market & 3 & 2.8 \\
\hline Internet infrastructure not consistent with emerging technologies & 2 & 1.9 \\
\hline Lack of a centralized portal for crowdsourcing & 1 & 0.9 \\
\hline Lack of financial and human resources & 1 & 0.9 \\
\hline Customer culture & 1 & 0.9 \\
\hline
\end{tabular}

Source: Authors

\subsection{Intention to implement emerging technologies}

The literature shows that six emerging technologies have applications in the area of logistics. Companies were then asked which of the six emerging technologies cited in literature motivated interest in financial investment. Responses were grouped into a variable that measures the intention to implement emerging technologies (IIET), shown in Table 7.

Table 7. Intention to implement emerging technologies (IIET).

\begin{tabular}{lcc}
\hline & $\begin{array}{c}\text { Frequency } \\
\text { (total 108) }\end{array}$ & $\%$ \\
\hline Low implementation & 46 & 42.6 \\
\hline Medium implementation & 38 & 35.2 \\
\hline High implementation & 24 & 22.2 \\
\hline
\end{tabular}

Source: Authors.

The possible values of IIET variable are:

a) Low implementation: companies that intend to adopt maximum of two of the six emerging technologies presented;

b) Medium implementation: companies that intend to adopt three or four of the six emerging technologies presented;

c) High implementation: companies that intend to adopt five or all six emerging technologies presented. 
Almost $60 \%$ of responding companies intend to implement three or more emerging technologies. The IIET variable is used in correlation tests in order to determine which factors impact the implementation of emerging technologies, shown below. $X 2$ tests (Pearson's chi-square) are used to investigate whether there are correlations between the IIET variable and the size, sector of activity and geographic location of the leadership of responding companies. The null hypotheses are:

$\mathrm{H}_{1}$ : There is no relationship between variable IIET and company size;

$\mathrm{H}_{2}$ : There is no relationship between variable IIET and sector in which the company operates;

$\mathrm{H}^{3}$ : There is no relationship between variable IIET and the geographical location of the company's leadership.

Table 8 presents the contingency table and results of the $x 2$ test for factor company size.

Table 8. Results of the $\mathrm{X} 2$ test for factor company size.

\begin{tabular}{|c|c|c|c|c|c|c|c|}
\hline \multirow[b]{3}{*}{ Company Size } & \multicolumn{7}{|c|}{ Intention to Implement Emerging Technologies (IIET) } \\
\hline & \multicolumn{2}{|c|}{$\begin{array}{c}\text { Low } \\
\text { Implementation }\end{array}$} & \multicolumn{2}{|c|}{$\begin{array}{c}\text { Medium } \\
\text { Implementation }\end{array}$} & \multicolumn{2}{|c|}{$\begin{array}{c}\text { High } \\
\text { Implementation }\end{array}$} & \multirow[b]{2}{*}{ 蛋 } \\
\hline & $\begin{array}{l}\text { তे } \\
\frac{c}{0} \\
\frac{0}{0} \\
\stackrel{0}{L}\end{array}$ & 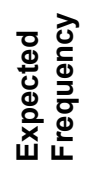 & 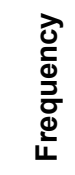 & 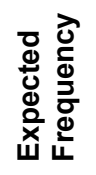 & $\begin{array}{l}\text { তे } \\
\text { d } \\
\frac{0}{0} \\
\frac{d}{1}\end{array}$ & 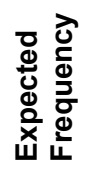 & \\
\hline Large Size & 10 & 15.8 & 16 & 13.0 & 11 & 8.2 & 37 \\
\hline Medium Size & 11 & 8.9 & 7 & 7.4 & 3 & 4.7 & 21 \\
\hline Small Size & 16 & 11.5 & 7 & 9.5 & 4 & 6.0 & 27 \\
\hline Micro-enterprise & 9 & 9.8 & 8 & 8.1 & 6 & 5.1 & 23 \\
\hline Total & 46 & 46.0 & 38 & 38.0 & 24 & 24.0 & 108 \\
\hline Significance Level & 0.05 & & & & & & \\
\hline $\mathrm{p}$-value & 0.229 & & & & & & \\
\hline $\begin{array}{l}\text { Degrees of } \\
\text { Freedom }\end{array}$ & 6 & & & & & & \\
\hline$x^{2}$-value & 8.12 & & & & & & \\
\hline
\end{tabular}

Source: Authors

The $\mathrm{H}_{1}$ hypothesis is rejected at significance level of $5 \%$. There is correlation between variable IIET and company size. Large companies intend to adopt greater number of emerging technologies than smaller ones. For $73 \%$ of large companies, the intention is to adopt more than 3 emerging technologies, placing them in the high implementation category, while for medium and small companies, efforts will be concentrated on a maximum of 2 emerging technologies. Table 9 presents the contingency table and the results of the $\mathrm{x} 2$ test for factor sector in which the company operates. 
Table 9. Results of the $\mathrm{x} 2$ test for factor sector in which company operates.

\begin{tabular}{|c|c|c|c|c|c|c|c|}
\hline \multirow{3}{*}{$\begin{array}{l}\text { Sector in which } \\
\text { company operates }\end{array}$} & \multicolumn{6}{|c|}{ Intention to Implement Emerging Technologies (IIET) } & \multirow[b]{3}{*}{ 恋 } \\
\hline & \multicolumn{2}{|c|}{$\begin{array}{c}\text { Low } \\
\text { Implementation }\end{array}$} & \multicolumn{2}{|c|}{$\begin{array}{c}\text { Medium } \\
\text { Implementation }\end{array}$} & \multicolumn{2}{|c|}{$\begin{array}{c}\text { High } \\
\text { Implementation }\end{array}$} & \\
\hline & $\begin{array}{l}\text { d̀ } \\
\frac{0}{0} \\
\frac{\partial}{0} \\
\frac{0}{4}\end{array}$ & 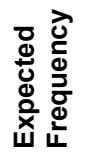 & $\begin{array}{l}\text { Jे } \\
\frac{c}{0} \\
\frac{\partial}{0} \\
\stackrel{d}{L}\end{array}$ & 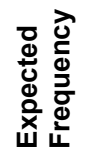 & $\begin{array}{l}\text { 현 } \\
\frac{c}{0} \\
\frac{\partial}{0} \\
\frac{d}{4}\end{array}$ & 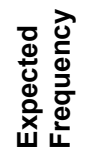 & \\
\hline e-Commerce & 2 & 14.9 & 6 & 12.3 & 0 & 7.8 & 8 \\
\hline Industry & 11 & 10.6 & 7 & 8.8 & 7 & 5.6 & 25 \\
\hline Retail & 4 & 3.0 & 2 & 2.5 & 1 & 1.6 & 7 \\
\hline Logistics Services & 18 & 14.9 & 9 & 12.3 & 8 & 7.8 & 35 \\
\hline Other Services & 8 & 11.5 & 12 & 9.5 & 7 & 6.0 & 27 \\
\hline Others & 3 & 2.6 & 2 & 2.1 & 1 & 1.3 & 6 \\
\hline Total & 46 & 57.5 & 38 & 47.5 & 24 & 30.1 & 108 \\
\hline Significance Level & 0.05 & & & & & & \\
\hline$p$-value & 0.362 & & & & & & \\
\hline Degrees of Freedom & 10 & & & & & & \\
\hline$x^{2}$-value & 10,947 & & & & & & \\
\hline
\end{tabular}

Source: Authors.

The $\mathrm{H}_{2}$ hypothesis is rejected by $\mathrm{p}$-value equal to 0.362 . The result implies that there is correlation between variable IIET and the sector in which the company operates. For $44 \%$ of companies in the industrial sector, the intention is to focus on maximum of 2 emerging technologies, placing them in the low implementation category. At the same time, companies in the logistics sector are equally divided, half of them planning low implementation and the other half planning medium or high implementation. Table 10 presents the contingency table and the results of the $\mathrm{X} 2$ test for factor geographic location of the company's leadership.

Table 10. Results of the $x 2$ test for factor location of the company's leadership.

\begin{tabular}{|c|c|c|c|c|c|c|c|}
\hline \multirow{3}{*}{$\begin{array}{c}\text { Region of Brazil where } \\
\text { the company's } \\
\text { headquarters is } \\
\text { located }\end{array}$} & \multicolumn{6}{|c|}{ Intention to Implement Emerging Technologies (IIET) } & \multirow[b]{3}{*}{ Total } \\
\hline & \multicolumn{2}{|c|}{$\begin{array}{c}\text { Low } \\
\text { Implementation }\end{array}$} & \multicolumn{2}{|c|}{$\begin{array}{c}\text { Medium } \\
\text { Implementation }\end{array}$} & \multicolumn{2}{|c|}{$\begin{array}{c}\text { High } \\
\text { Implementation }\end{array}$} & \\
\hline & $\begin{array}{l}\text { তे } \\
\frac{c}{0} \\
\frac{0}{0} \\
\frac{d}{L}\end{array}$ & 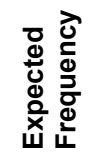 & $\begin{array}{l}\text { তे } \\
\frac{c}{0} \\
\frac{0}{0} \\
\frac{d}{L}\end{array}$ & 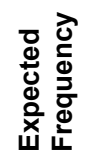 & $\begin{array}{l}\text { তे } \\
\frac{c}{0} \\
\frac{0}{0} \\
\frac{0}{4}\end{array}$ & 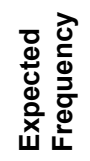 & \\
\hline Northern & 0 & 0.00 & 0 & 0.00 & 0 & 0.00 & 0 \\
\hline Northeastern & 2 & 2.60 & 2 & 2.10 & 2 & 1.30 & 6 \\
\hline Midwestern & 1 & 1.30 & 2 & 1.10 & 0 & 0.70 & 3 \\
\hline Southeastern & 31 & 30.70 & 27 & 25.30 & 14 & 16.00 & 72 \\
\hline Southern & 12 & 11.50 & 7 & 9.50 & 8 & 6.00 & 27 \\
\hline Total & 46 & 46.10 & 38 & 38.00 & 24 & 24.00 & 108 \\
\hline Significance Level & 0.05 & & & & & & \\
\hline$p$-value & 0.712 & & & & & & \\
\hline Degrees of Freedom & 6 & & & & & & \\
\hline$x^{2}$-value & 3.742 & & & & & & \\
\hline
\end{tabular}

Source: Authors. 
The $\mathrm{H}_{3}$ hypothesis is rejected. There is correlation between variable IITE and the location of the company's leadership. Table 11 shows the summary of expected gains and time for the implementation of emerging technologies.

Table 11. Summary of gain expectation and expected time to realize gain through investments in emerging technologies.

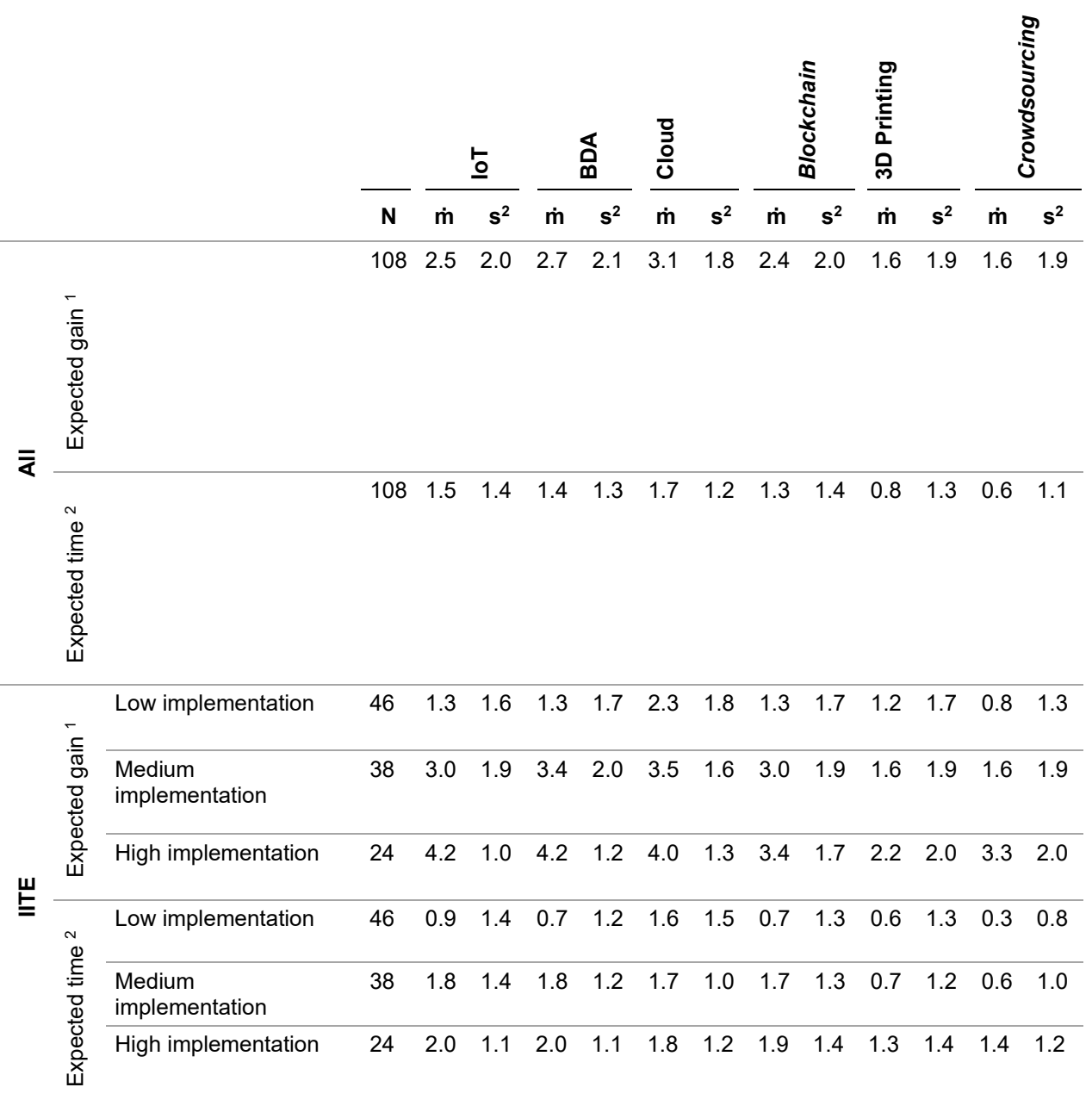

$\mathrm{N}$ : Number of responses. m: Mean. $\mathrm{s}^{2}$ : Standard deviation. ${ }^{1}: 1$ - [0] does not apply/did not respond, [1] no gain, [2] little gain, [3] medium gain, [4] high gain and [5] high gain. 2: [0] does not apply/did not respond, [1] today, [2] short term (<= 1 year, [3] medium term (2-5 years), [4] long term ( $>5$ years). Source: Authors.

Table 11 shows that when considering all respondents, cloud technology has the highest gain expectation regarding financial investments, followed by BDA. Although loT has the highest adoption intention, as shown in Table 3, it is the third place when measuring gain expectation. No technology has expected time to achieve gains greater than 2.0, which demonstrates that companies want to obtain gains from the implementation of emerging technologies immediately after their implementation. The high coefficient of variation that appears in the compilation of results denotes high dispersion in responses regarding gain expectation and time of investment in emerging 
technologies, indicating that responding companies do not have a homogeneous opinion regarding investments in these technologies.

\subsection{Data quality of responding companies}

The use of emerging technologies in logistics requires that company data are correctly organized and available. In order to measure the quality of data stored in companies, were formulated based on the follow affirmatives $\left(A_{n}\right)$ and the respective null hypotheses $\left(\mathrm{H}_{\mathrm{n}}\right)$ :

Affirmative $A_{1}$ : My company data is stored in appropriate formats (trusted).

Hypotheses $\mathrm{H}_{4}$ : Data reliability is the same for companies of any size and any intention to implement emerging technologies (IIET).

Affirmative $A_{2}$ : I have easy access to my company's data (accessible).

Hypotheses $\mathrm{H}_{5}$ : Data accessibility by users is the same for companies of any size and any intention to implement emerging technologies.

Affirmative $A_{3}$ : All organizational functions have the same data (unique).

Hypotheses $\mathrm{H}_{6}$ : Data uniqueness is present in companies of any size and any intention to implement emerging technologies;

Affirmative $A_{4}$ : My company data can be exchanged with my supply chain (available).

Hypotheses $\mathrm{H}_{7}$ : Data availability by users is the same for companies of any size and any intention to implement emerging technologies.

Affirmative $A_{5}$ : My company already exchanges data and information with suppliers and I or customers (collaborative)

Hypotheses $\mathrm{H}_{8}$ : The level of data collaboration with customers and suppliers is the same for companies of any size and any intention to implement emerging technologies.

Table 12 shows the results of the follow-up test in ANOVA for statements about data quality using the Scheffe's procedure, showing descriptive statistics for each of the statements. Each statement was considered as a dependent variable in data analysis segmented by company size and using variable IIET, intention to implement emerging technologies, as a fixed factor in the test.

Table 12. Quality of company data (ANOVA).

\begin{tabular}{|c|c|c|c|c|c|c|c|c|c|c|c|c|c|c|c|c|c|c|c|}
\hline \multirow{3}{*}{$\begin{array}{l}\text { Company } \\
\text { Size }\end{array}$} & \multirow{3}{*}{ IIET } & \multicolumn{18}{|c|}{ Quality of data } \\
\hline & & \multicolumn{3}{|c|}{$\mathbf{A}_{1}$} & \multicolumn{4}{|c|}{$A_{2}$} & \multicolumn{4}{|c|}{$\mathrm{A}_{3}$} & \multicolumn{4}{|c|}{$\mathrm{A}_{4}$} & \multicolumn{3}{|c|}{$A_{5}$} \\
\hline & & $\mathbf{N}$ & $\dot{\mathrm{m}} \mathrm{s}^{2}$ & $S$ & $\mathbf{N}$ & $\dot{\mathbf{m}}$ & $\mathrm{s}^{2}$ & $S$ & $\mathbf{N}$ & $\dot{\mathbf{m}}$ & $\mathrm{s}^{2}$ & $S$ & $\mathbf{N}$ & $\dot{\mathbf{m}}$ & $\mathrm{s}^{2}$ & $S$ & $\mathbf{N}$ & $\dot{\mathrm{m}} \mathrm{s}^{2}$ & $S$ \\
\hline \multirow{3}{*}{ Large size } & $\begin{array}{l}\text { Low } \\
\text { implementation }\end{array}$ & 10 & 3.61 .4 & 0.4 & 10 & 3.8 & 1.3 & 0.1 & 10 & 2.9 & 1.5 & 0.1 & 10 & 3.4 & 1.5 & 0.2 & 10 & 3.41 .60 & 0.7 \\
\hline & $\begin{array}{l}\text { Medium } \\
\text { implementation }\end{array}$ & 16 & 3.51 .5 & 0.4 & 16 & 3.1 & 1.3 & 0.1 & 16 & 2.6 & 1.4 & 0.1 & 16 & 2.7 & 1.6 & 0.2 & 16 & 3.01 .60 & 0.7 \\
\hline & $\begin{array}{l}\text { High } \\
\text { implementation }\end{array}$ & 11 & 4.21 .2 & 0.4 & 11 & 4.1 & 1.2 & 0.1 & 11 & 3.8 & 1.3 & 0.1 & 11 & 3.7 & 1.3 & 0.2 & 11 & 3.51 .40 & 0.7 \\
\hline \multirow{3}{*}{ Medium size } & $\begin{array}{l}\text { Low } \\
\text { implementation }\end{array}$ & 11 & 3.51 .8 & 0.9 & 11 & 4.2 & 1.2 & 0.8 & 11 & 2.6 & 1.4 & 0.3 & 11 & 3.5 & 1.8 & 0.5 & 11 & 2.91 .60 & 0.6 \\
\hline & $\begin{array}{l}\text { Medium } \\
\text { implementation }\end{array}$ & 7 & 3.61 .8 & 0.9 & 7 & 4.4 & 0.8 & 0.8 & 7 & 3.6 & 1.3 & 0.3 & 7 & 4.3 & 1.1 & 0.5 & 7 & 3.72 .30 & 0.6 \\
\hline & $\begin{array}{l}\text { High } \\
\text { implementation }\end{array}$ & 3 & 4.01 .0 & 0.9 & 3 & 4.0 & 1.0 & 0.8 & 3 & 3.0 & 0.0 & 0.3 & 3 & 3.3 & 2.1 & 0.5 & 3 & 2.31 .90 & 0.6 \\
\hline
\end{tabular}


Table 12. Continued...

\begin{tabular}{|c|c|c|c|c|c|c|c|c|c|c|c|c|c|c|c|c|c|c|c|c|c|}
\hline \multirow{3}{*}{$\begin{array}{c}\text { Company } \\
\text { Size }\end{array}$} & \multirow{3}{*}{ IIET } & \multicolumn{20}{|c|}{ Quality of data } \\
\hline & & \multicolumn{4}{|c|}{$\mathbf{A}_{1}$} & \multicolumn{4}{|c|}{$\mathbf{A}_{2}$} & \multicolumn{4}{|c|}{$\mathbf{A}_{3}$} & \multicolumn{4}{|c|}{$\mathbf{A}_{4}$} & \multicolumn{4}{|c|}{$A_{5}$} \\
\hline & & $\mathbf{N}$ & m & $\mathrm{s}^{2}$ & $\bar{S}$ & $\mathbf{N}$ & $\dot{\mathbf{m}}$ & $s^{2}$ & $\mathrm{~S}$ & $\mathbf{N}$ & $\dot{\mathbf{m}}$ & $s^{2}$ & 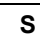 & $\mathbf{N}$ & $\dot{\mathbf{m}}$ & $\mathrm{s}^{2}$ & $S$ & $\mathbf{N}$ & m & $\mathrm{s}^{2}$ & $\mathbf{S}$ \\
\hline \multirow[t]{4}{*}{ Small size } & $\begin{array}{l}\text { Low } \\
\text { implementation }\end{array}$ & 16 & 4.2 & 1.4 & 0.1 & 16 & 4.3 & 1.2 & 0.7 & 16 & 3.4 & 1.6 & 0.4 & 16 & 3.1 & 1.8 & 0.3 & 16 & 3.3 & 2.1 & 0.8 \\
\hline & $\begin{array}{l}\text { Medium } \\
\text { implementation }\end{array}$ & 7 & 2.9 & 1.7 & 0.1 & 7 & 3.9 & 1.2 & 0.7 & 7 & 2.6 & 1.8 & 0.4 & 7 & 4.3 & 1.1 & 0.3 & 7 & 3.9 & 1.6 & 0.8 \\
\hline & $\begin{array}{l}\text { High } \\
\text { implementation }\end{array}$ & 4 & 2.8 & 1.7 & 0.1 & 4 & 4.0 & 1.2 & 0.7 & 4 & 4.0 & 1.4 & 0.4 & 4 & 4.0 & 1.4 & 0.3 & 4 & 3.8 & 1.9 & 0.8 \\
\hline & $\begin{array}{l}\text { Low } \\
\text { implementation }\end{array}$ & 9 & 2.9 & 1.8 & 0.3 & 9 & 3.2 & 2.0 & 0.2 & 9 & 2.2 & 1.9 & 0.1 & 9 & 2.3 & 1.8 & 0.5 & 9 & 1.9 & 1.7 & 0.1 \\
\hline \multirow[t]{2}{*}{$\begin{array}{l}\text { Micro- } \\
\text { enterprise }\end{array}$} & $\begin{array}{l}\text { Medium } \\
\text { implementation }\end{array}$ & 8 & 2.5 & 1.2 & 0.3 & 8 & 4.1 & 1.4 & 0.2 & 8 & 2.8 & 1.2 & 0.1 & 8 & 3.1 & 1.5 & 0.5 & 8 & 3.0 & 1.1 & 0.1 \\
\hline & $\begin{array}{l}\text { High } \\
\text { implementation }\end{array}$ & 6 & 3.8 & 1.6 & 0.3 & 6 & 4.7 & 0.8 & 0.2 & 6 & 4.0 & 1.1 & 0.1 & 6 & 3.3 & 1.5 & 0.5 & 6 & 4.2 & 1.0 & 0.1 \\
\hline
\end{tabular}

S = Standard deviation. Source: Authors.

The null hypotheses are all accepted, that is, companies declare that their data are reliable, accessible, unique, available and ready to collaborate with their supply chain, regardless of company size and IIET. Responding companies that intend to adopt emerging technologies believe they have adequate data quality, which, according to literature, is a sine qua non condition for the use of these technologies.

\section{Conclusions and recommendations}

This work identified which emerging technologies, based on literature and linked to the concept of Logistics 4.0, are of financial interest to consulted or responding companies. In addition, what are the intended applications for these technologies, the barriers for their adoption, the expected gains and in what time will these gains occur and if company data, prerequisite for the adoption of emerging technologies, according to respondents, have adequate quality.

In relation to sample, it could be seen in the results of questionnaires that responses included information on different business and sizes, so the adoption of logistical solutions varies according to size, performance capillarity and available resources to be managed.

Most large companies intend to adopt three or four of the six technologies mentioned in this study (43\%), being then part of the group of medium intention to implement emerging technologies.

Most medium (52\%) and small companies (59\%) intend to adopt maximum of two technologies, being part of the companies with low intention to implement emerging technologies.

Many micro-enterprises have similar intentions to adopt emerging technologies, with the majority of them (39\%) belonging to the low implementation group, a number close $(35 \%)$ to those belonging to the medium implementation group and, finally, there is high number of micro-enterprises $(26 \%)$ that intend to adopt five or all six emerging technologies, belonging to the high implementation group.

Another highlight is the relationship between financial gain, gain time and intention to implement technologies: the more emerging technologies companies intend to adopt, the greater the gain expectation and the longer the time they wait to realize this gain. 
As for the intention to implement emerging technologies, this study shows that the two most interesting technologies among responding companies are loT and cloud, both with $82 \%$ of investment intent. These two technologies are those that currently receive most investments from companies, accounting for $65 \%$ of respondents. The two least interesting technologies among responding companies are crowdsourcing and $3 \mathrm{D}$ printing, both with $68 \%$ of disinterest among respondents. This result is consistent with the study by Rogers et al. (2017), which shows the growth in the use of these technologies in North American companies. Regarding the expected gain in investment in emerging technologies, companies see greater opportunity for gain in cloud investment, with expected average gain of 3.08 , followed by BDA, with average gain of 2.67. IoT practically equals BDA, with average gain of 2.54. The worst expectation of gain is in 3D printing technology, with average gain of 1.61.

Regarding the estimated time to realize gains with investment in emerging technologies, it is clear that the expectation is for short-term gains (within one year) for all technologies, with the greatest expectation of gain by investing in the cloud technology, with average of 1.66 and the greatest expectation is for crowdsourcing technology, with average of 0.63 .

Among applications intended with the implementation of emerging technologies, the use of blockchain for cargo tracking and smart contracts stands out, with $13 \%$ of responses, followed by the use of 3D printing for local printing of small components, with $6 \%$ of responses.

Among factors that affect the implementation of emerging technologies, high investments in software and hardware stands out, reported by $42 \%$ of respondents, followed by high investments in human resources, mentioned by $33 \%$ of professionals. The lack of adoption strategy for emerging technologies appears with $29 \%$ of responses.

The hypothesis tests, carried out on data quality issues, show that responding companies, regardless of size and intention to implement emerging technologies, believe they have adequate degree of data quality, which is a condition for the adoption of emerging technologies.

There are currently no studies on the joint application of the six technologies mentioned in this study; however, it is possible to compare some results. Regarding the adoption of loT technology, Tu (2018) reported that, in a study with 130 executive managers of Taiwanese companies, the average gain expectation is 4.39 on the same scale adopted in this work, while responding companies have average gain expectation of 2.54, when all respondents are considered. These results show that executives from Taiwanese companies believe that loT will bring greater gains to operations than Brazilian executives. Regarding data quality, the study by Rogers et al. (2017), with 127 North American logistics professionals, found that most of these executives are satisfied with the quality of their companies' data, the same result reported by Brazilian logistics professionals. Another finding by Rogers et al. (2017) deals with the current stage of investments in BDA technology. The North American study shows that $61 \%$ of respondents already invest in BDA technology, a number close to that of Brazilian companies, which is $56 \%$. This survey included 108 valid questionnaires in a population of 26,000 companies. Although the survey is valid and includes experienced respondents, who occupy high positions in companies, it is desirable to apply the questionnaire to a larger number of companies, increasing the survey significance. A limitation imposed by a small number of responses is the violation of multivariate normality, which is usual in investigations of this type, which can cause result biases. 
For future studies, we suggest reapplying this study to a larger number of companies to verify how results vary in a larger sample. Another study limitation is the absence of a robust financial analysis, which is explained by the difficulty in obtaining such data from companies, since the majority of respondents are prevented from providing data due to confidentiality agreements.

\section{References}

Bhoir, H., \& Principal, R. P. (2014). Cloud computing for supply chain management. International Journal of Innovations in Engineering Research and Technology, 1(2), 1-9.

Bocek, T., Rodrigues, B., Strasser, T., \& Stiller, B. (2017). Blockchains everywhere: a use-case of blockchains in the pharma supply-chain. In 2017 IFIP/IEEE Symposium on Integrated Network and Service Management (IM). New York: IEEE.

Carbone, V., Rouquet, A., \& Roussat, C. (2017). The rise of crowd logistics: a new way to cocreate logistics value. Journal of Business Logistics, 38(4), 238-252. http://dx.doi.org/10.1111/jbl.12164.

Carbone, V., Rouquet, A., \& Roussat, C. (2018). A typology of logistics at work in collaborative consumption. International Journal of Physical Distribution \& Logistics Management, 48(6), 570-585. http://dx.doi.org/10.1108/IJPDLM-11-2017-0355.

Castillo, V. E., Bell, J. E., Rose, W. J., \& Rodrigues, A. M. (2018). Crowdsourcing last mile delivery: strategic implications and future research directions. Journal of Business Logistics, 39(1), 7-25. http://dx.doi.org/10.1111/jbl.12173.

Christidis, K., \& Devetsikiotis, M. (2016). Blockchains and smart contracts for the internet of things. IEEE Access: Practical Innovations, Open Solutions, 4, 2292-2303. http://dx.doi.org/10.1109/ACCESS.2016.2566339.

Council of Supply Chain Management Professionals - CSCMP. (2017). CSCMP supply chain management definitions and glossary. Illinois.

Dai, H., Ge, L., \& Zhou, W. (2015). A design method for supply chain traceability systems with aligned interests. International Journal of Production Economics, 170, 14-24. http://dx.doi.org/10.1016/j.jpe.2015.08.010.

Dong, Y., Carter, C. R., \& Dresner, M. E. (2001). JIT purchasing and performance: an exploratory analysis of buyer and supplier perspectives. Journal of Operations Management, 19(4), 471-483. http://dx.doi.org/10.1016/S0272-6963(00)00066-8.

Drees, J. (2016). Logistics 4.0: tailored solutions for the future. In International Press Workshop. Chennai: Gopali \& Co.

Durach, C. F., Kurpjuweit, S., \& Wagner, S. M. (2017). The impact of additive manufacturing on supply chains. International Journal of Physical Distribution \& Logistics Management, 47(10), 954-971. http://dx.doi.org/10.1108/IJPDLM-11-2016-0332.

Goldsby, T. J., \& Zinn, W. (2016). Technology Innovation and New Business Models: can logistics and supply chain research accelerate the evolution? Journal of Business Logistics, 37(2), 80-81. http://dx.doi.org/10.1111/jbl.12130.

Gubbi, J., Buyya, R., Marusic, S., \& Palaniswami, M. (2013). Internet of Things (IoT): a vision, architectural elements, and future directions. Future Generation Computer Systems, 29(7), 1645-1660. http://dx.doi.org/10.1016/j.future.2013.01.010.

Hofmann, E. (2017). Big data and supply chain decisions: the impact of volume, variety and velocity properties on the bullwhip effect. International Journal of Production Research, 55(17), 5108-5126. http://dx.doi.org/10.1080/00207543.2015.1061222. 
Hofmann, E., \& Rüsch, M. (2017). Industry 4.0 and the current status as well as future prospects on logistics. Computers in Industry, 89, 23-34.

http://dx.doi.org/10.1016/j.compind.2017.04.002.

Howe, J. (2006). The rise of crowdsourcing. Wired Magazine., 14(6), 1-5.

Instituto Brasileiro de Geografia e Estatística - IBGE. (2018). Contas nacionais trimestrais. Rio de Janeiro.

Kim, S., \& Kim, S. (2016). A multi-criteria approach toward discovering killer loT application in Korea. Technological Forecasting and Social Change, 102, 143-155. http://dx.doi.org/10.1016/j.techfore.2015.05.007.

Kshetri, N. (2018). 1 Blockchain's roles in meeting key supply chain management objectives. International Journal of Information Management, 39, 80-89. http://dx.doi.org/10.1016/j.jijinfomgt.2017.12.005.

Kubáč, L., \& Kodym, O. (2017). The impact of 3D printing technology on supply chain. MATEC Web of Conferences, 134, 27-37. http://dx.doi.org/10.1051/matecconf/201713400027.

Lambert, D. M. (1975). The development of an inventory costing methodology: a study of the costs associated with holding enventory. Ohio: The Ohio State University Press.

Lindner, M., Galán, F., Chapman, C., Clayman, S., Henriksson, D., \& Elmroth, E. (2010). The Cloud Supply Chain: a framework for information, monitoring, accounting and billing. In $2 n d$ International ICST Conference on Cloud Computing. Budapest: Budapest Science Portals.

Lu, Y., Papagiannidis, S., \& Alamanos, E. (2018). Internet of things: a systematic review of the business literature from the user and organisational perspectives. Technological Rorecasting and Social Change., 136, 285-297. http://dx.doi.org/10.1016/j.techfore.2018.01.022.

Parasuranan, A., Grewal, D., \& Krishnan, R. (2006). Marketing research (2nd ed.). Nashville: Southwestern Publishing Group.

Pfohl, H., Yahsi, B., \& Kurnaz, T. (2015). The impact of Industry 4.0 on the Supply Chain. In Proceedings of the Hamburg International Conference of Logistic (pp. 32-58). Hamburg.

Richey, R. G., Jr., Morgan, T. R., Lindsey-Hall, K., \& Adams, F. G. (2016). A global exploration of Big Data in the supply chain. International Journal of Physical Distribution \& Logistics Management, 46(8), 710-739. http://dx.doi.org/10.1108/IJPDLM-05-2016-0134.

Rogers, H., Baricz, N., \& Pawar, K. S. (2016). 3D printing services: classification, supply chain implications and research agenda. International Journal of Physical Distribution \& Logistics Management, 46(10), 886-907. http://dx.doi.org/10.1108/IJPDLM-07-2016-0210.

Rogers, Z., Gooley, T., Harrington, L., Rogers, D., Sharpe, R., \& Kitajima, T. (2017). Big data analytics in supply chain: tackling the tidal wave (pp. 1-6). CSCMP's Supply Chain Quarterly.

Rossmann, B., Canzaniello, A., Von der Gracht, H., \& Hartmann, E. (2018). The future and social impact of Big Data Analytics in Supply Chain Management: results from a Delphi study. Technological Forecasting and Social Change, 130, 135-149. http://dx.doi.org/10.1016/j.techfore.2017.10.005.

Sasson, A., \& Johnson, J. C. (2016). The 3D printing order: variability, supercenters and supply chain reconfigurations. International Journal of Physical Distribution \& Logistics Management, 46(1), 82-94. http://dx.doi.org/10.1108/IJPDLM-10-2015-0257.

Strandhagen, J. O., Vallandingham, L. R., Fragapane, G., Strandhagen, J. W., Stangeland, A. B. H., \& Sharma, N. (2017). Logistics 4.0 and emerging sustainable business models. Advances in Manufacturing., 5(4), 359-369. http://dx.doi.org/10.1007/s40436-017-0198-1.

Tiwari, S., Wee, H. M., \& Daryanto, Y. (2018). Big Data Analytics in Supply Chain Management Between 2010 and 2016: insights to Industries. Computers \& Industrial Engineering, 115, 319-330. http://dx.doi.org/10.1016/j.cie.2017.11.017. 
Tu, M. (2018). An exploratory study of Internet of Things (IoT) adoption intention in logistics and supply chain management: a mixed research approach. International Journal of Logistics Management, 29(1), 131-151. http://dx.doi.org/10.1108/IJLM-11-2016-0274.

Varela Rozados, I. \& Tjahjono, B. (2014). Big data analytics in supply chain management: trends and related research. In Proceedings of the 6th International Conference on Operations and Supply Chain Management. Bali.

Vazquez-Martinez, G. A., Gonzalez-Compean, J. L., Sosa-Sosa, V. J., Morales-Sandoval, M., \& Perez, J. C. (2018). CloudChain: a novel distribution model for digital products based on supply chain principles. International Journal of Information Management, 39, 90-103. http://dx.doi.org/10.1016/j.jijnfomgt.2017.12.006.

Vilela, L. O. (2012). Aplicação do ProKnow-C para seleção de um portifólio bibliográfico e análise bibliométrica sobre avaliação de desempenho da gestão do conhecimento. Revista Gestão Industrial., 8(1), 76-92. http://dx.doi.org/10.3895/S1808-04482012000100005.

Waller, M. A., \& Fawcett, S. E. (2013). Data scientist: big data, predictive analytics, and theory development in the era of a maker movement supply chain. Journal of Business Logistics, 34(4), 249-252. http://dx.doi.org/10.1111/jbl.12024.

Waller, M. A., \& Fawcett, S. E. (2014). Print a maker movement supply chain: how invention and entrepreneurship will disrupt supply chain design. Journal of Business Logistics, 35(2), 99. http://dx.doi.org/10.1111/jbl.12045.

Wang, K. (2016) Logistics 4.0 solution: new challenges and opportunities. In Proceedings of the 6th International Workshop of Advanced Manufacturing and Automation. The Netherlands: Atlantis Press. http://dx.doi.org/10.2991/iwama-16.2016.13.

Zhong, R. Y., Newman, S. T., Huang, G. Q., \& Lan, S. (2016). Big data for supply chain management in the service and manufacturing sectors: challenges, opportunities, and future perspectives. Computers \& Industrial Engineering, 101, 572-591. http://dx.doi.org/10.1016/j.cie.2016.07.013. 


\section{Supplementary Material}

Supplementary material accompanies this paper.

Data availability statement: http://dx.doi.org/10.17632/gk4p9r6bpt.2

This material is available as part of the online article from http://www.scielo.br/gp 